Check for updates

New York

Cite this as: $B M J 2020 ; 371: \mathrm{m} 3948$ http://dx.doi.org/10.1136/bmj.m3948 Published: 12 October 2020

\section{Covid-19: At least two thirds of 225000 excess deaths in US were due to virus}

\author{
Janice Hopkins Tanne
}

The US had more than 225000 excess deaths between March and July this year, and about two thirds of them were due to covid-19, reports a study published online in JAMA by authors from Virginia Commonwealth University School of Medicine and Yale School of Public Health.

When compared with 18 other countries the US had high covid-19 mortality and high excess mortality, said researchers from Harvard and the University of Pennsylvania. ${ }^{2}$ If the US had the same death rate as Australia, 187661 Americans would still be alive, they estimated. If the US had the same death rate as Canada 117622 Americans would still be alive. It was not clear whether this pattern would continue through the autumn, the authors said.

Deaths in the US and other countries show a regular pattern, increasing in winter and decreasing in summer. When there is an abrupt event such as a pandemic the "excess mortality can be a revealing indicator of the death toll from that event," said Harvey Fineberg in an editorial in JAMA. ${ }^{3}$ He is former president of the Institute of Medicine (now the National Academy of Medicine) and current president of the Gordon and Betty Moore foundation in Palo Alto, California

From March to the end of July there were 1336561 deaths in the US, a 20\% increase over the 1111031 expected deaths. Covid-19 was documented as the cause in $67 \%$ of the deaths, but the other deaths may also be related to the virus. A study of excess mortality during the early epidemic in March and April showed that $65 \%$ of excess deaths were due to covid-19 and other excess deaths were due to Alzheimer's disease, diabetes, and heart disease in the five states with the most deaths. ${ }^{4}$

Later excess deaths-from March to the end of July-that were attributed to causes other than covid-19 could reflect deaths from unrecognised or undocumented covid-19 infections or deaths from disruptions caused by the pandemic. Many people did not seek medical attention for apparently serious conditions such as myocardial infarction and strokes because they feared being infected with the covid-19 virus in hospitals.

The increase in deaths relative to expected values ranged from $22 \%$ in Rhode Island and Michigan to $65 \%$ in New York. The three northeastern states with the highest death rates, New York, New Jersey, and Massachusetts, accounted for $30 \%$ of US excess deaths but had the shortest epidemics, the authors wrote.

An international comparison showed that the US had more deaths from covid-19 than any other country and one of the highest cumulative per capita death rates. The US was compared with 17 other countries that were grouped as having low (less than five deaths per 100 ooo population), moderate (5-25 deaths per 100 000), or high mortality (more than 25 deaths per 100 000).

The high mortality countries were the Netherlands, France, Sweden, Italy, the UK, Spain, Belgium, and the US. The US mortality rate since the start of the epidemic was 60.3 per 100 ooo, and the UK mortality rate was 62.6 per 100 ooo. The low mortality countries, South Korea, Japan, and Australia, had rates of $0.7,1.2$, and 3.3 per 100000.

The high covid-19 mortality and excess all cause mortality in the US may have been due to a "weak public health infrastructure and a decentralized, inconsistent US response to the pandemic," the researchers said. Also, the US population is younger than in many comparison countries but has more comorbidities. $^{2}$

1 Woolf SH, Chapman DA, Sabo RT, Weinberger DM, Hill L. Excess deaths from covid-19 and other causes, March-July 2020. JAMA 2020;324:510-3. doi: 10.1001/jama.2020.11787. pmid: 32609307

2 Bilinski A, Emanuel EJ. Covid-19 and excess all-cause mortality in the US and 18 comparison countries. JAMA 2020;(Oct). doi: 10.1001/jama.2020.20717

3 Fineberg HV. The toll of covid-19. JAMA 2020;(Oct). doi: 10.1001/jama.2020.20019. pmid: 32525535

4 Woolf SH, Chapman DA, Sabo RT, Weinberger DM, Hill L. Excess deaths from covid-19 and other causes, March-April 2020. JAMA 2020;324:510-3. doi: 10.1001/jama.2020.11787. pmid: 32609307

This article is made freely available for use in accordance with BMJ's website terms and conditions for the duration of the covid-19 pandemic or until otherwise determined by BMJ. You may use, download and print the article for any lawful, non-commercial purpose (including text and data mining) provided that all copyright notices and trade marks are retained. 